\title{
Effects of rearing method on some morphological and reproductive organ characteristics of queen honey bees (Apis mellifera L.)"
}

\author{
GONCA OZMEN OZBAKIR
}

Department of Animal Science, Faculty of Agriculture, Harran University, Sanliurfa, Turkey

\section{Ozmen Ozbakir G. \\ Effects of rearing method on some morphological and reproductive organ characteristics of queen honey bees (Apis mellifera L.)}

\section{Summary}

This study aimed to investigate some of the morphological and reproductive characteristics of the queen honey bees rearing from emergency queen cells and larvae grafting method. The weight at the emergence of queens reared from one-day larvae was found to be higher than other groups $(\mathrm{P}<0.05)$. Morphological characteristics of queens according to rearing method showed significant differences of head width, forewing length and forewing width $(\mathrm{P}<\mathbf{0 . 0 5})$, whereas other morphological characteristics were found similar in different queen groups. No significant difference was observed between the groups in terms of cell length and width $(P>0.05)$. Wet ovary weights of the queens were weighed at 45,51 , and $49 \mathrm{mg}$ rearing from emergency cells, 1-day-old and 2-day-old larvae, respectively. The number of ovarioles and spermatheca diameter of queens were found to be 268 and $1.14 \mathrm{~mm}, 296$ and $1.21 \mathrm{~mm}, 285$, and $1.16 \mathrm{~mm}$ rearing from emergency cells, 1-day-old and 2-day-old larvae, respectively $(\mathrm{P}<\mathbf{0 . 0 5})$. Consequently, the morphological and reproductive characteristics of queens reared from one-day-old larvae have higher values. According to the results of the study, although some morphological and reproductive features of local queens have low values, their importance should not be ignored in the sustainable future of beekeeping.

Keywords: Apis mellifera, honey bee, queen morphometry, queen rearing, queen reproductive characters

In western honey bee colonies, the queen, who is the only individual capable of mating and laying fertilized eggs, is responsible for reproduction. The survival of the colony depends on the queen and her reproductive capability $(2,3,37)$. The queen honey bee is the most important individual within the colony for both social and genetic reasons. Evaluation of the reproductive capacity of queens can provide useful information about factors affecting the colony fitness $(8,30)$. Workers raise new queens in cases of emergency (to replace dead or missing queens), supersedure (to replace old or injured or diseased queens) and swarm situations $(4,31)$.

Numerous studies have been conducted to determine the reproductive capacity and quality of queen honey bees. The quality of the queens is affected by genotype, rearing methods, rearing season, nutrition, age of larvae, and the number of grafting larvae. A queen's quality can be identified by measuring her morpho-

1) This study was presented as a poster (abstract) at the $6^{\text {th }}$ International Muğla Beekeeping \& Pine Honey Congress, 15-19 Oct 2018, Turkey. logical features and her reproductive organs $(12,14$, $16,18,33)$. There are some physical characteristics that would make a queen superior to reproduction; metabolism, larger ovaries, longer ovarioles, and large spermatheca (32).

While the age of grafted larvae increases, the size of the spermatheca, the number of ovarioles in the ovaries, and the bodyweight of the queen decreases. Moreover, queen weight at emergence is correlated with the size of the spermatheca and the number of ovarioles (42, 43). According to morphology and sperm count, queens raised from old larvae are of low quality, and subsequently they also mate with significantly fewer males (33). Queen weight has a significant effect on the onset of oviposition, acceptance ratio of queens, number of spermatozoa in the spermatheca, the diameter of spermatheca, and laying rate (1). In order to express queen-quality, some morphological features such as head width, thorax width, and wing lengths have been examined $(7,14,16)$. A significant decrease was found in the number of ovarioles per ovary as the age 
of the grafted larvae increased and it was reported that there was a correlation between the decreasing number of ovarioles and basitarsus index (7). The thorax width of queens was positively correlated with both mating frequency and stored sperm number (8). In a study examining the morphological and reproductive characteristics of queens rearing from 0 - and 2-days-old larvae, there was a difference between the two groups in terms of wet weight and thorax width, but there was no difference in terms of head width (33). The wing lengths of the queens were not affected by different larvae ages and supplemental feeding (20).

In queenless colonies, workers begin queen rearing with larvae less than 2-days-old (41). According to Hatch et. al. (16) emergency queen rearing

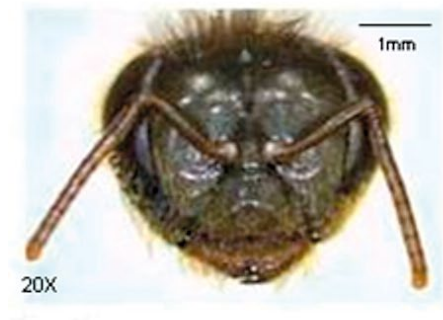

head

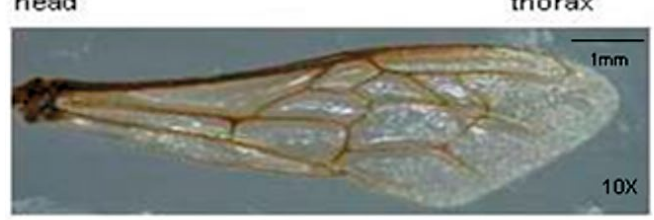

foreving

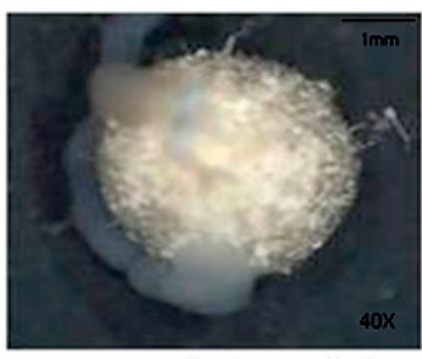

spermatheca with tracheal net

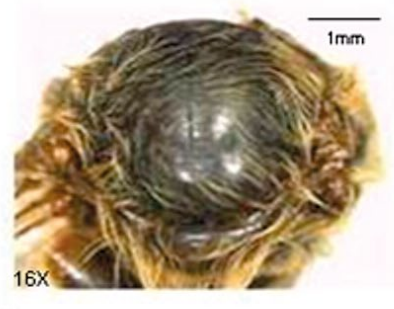

thorax

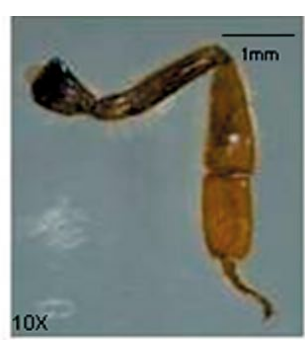

hind leg

Fig. 1. Microscope images of queen morphological and reproductive organ characteristics process started within $24 \mathrm{~h}$.

Workers coordinate the requeening process by building a different number of cells and differentially constructing cells from varied ages of the brood. However, workers destroyed half of the cells before the emergence of the queens. Queen quality and development time are determined by many factors during emergency queen rearing. Nutrition, temperature, the position of the queen cell in the nest, and brood composition and genetic factors affect the queen quality $(11,27,35,38)$.

Beekeepers generally tend to rear queens from their colonies or purchase queens from other localities. The qualities of these queens are unknown. In addition to adapting to the hot and arid climate of the province, local honey bee genotypes can be improved for queen rearing and for future breeding programs. The purpose of this study was to investigate the effects of rearing methods to some morphological and reproductive characteristics of the queens rearing from emergency queen cells and larvae grafting method in the semi-arid climatic conditions. This study aims to contribute to the understanding of the quality parameters of the queens, especially those rearing from emergency cells without supplemental feeding.

\section{Material and methods}

Experimental set up and queen rearing. This study was conducted in Apiculture Research and Application Unit of Agriculture Faculty of Harran University. The experiment was carried out between May and August 2018 at Sanliurfa province in the Southeast Anatolian Region of Turkey ( $37^{\circ} 11^{\prime} 05^{\prime \prime} \mathrm{N}$ and $\left.38^{\circ} 59^{\prime} 40^{\prime \prime} \mathrm{E}\right)$. Sanliurfa has a continen- tal climate and is very dry and hot in the summer. The live material for the study was local honey bees, Apis mellifera of Sanliurfa. Morphological, behavioral and performance characteristics of local honey bee colonies were examined in previous studies $(22,23)$.

The standard queen rearing process was followed (19). One-day- and 2-day-old larvae were obtained from a source colony that the queen was confined with an empty honeycomb for grafting. Two equally strong, queenless starter colonies were prepared and 40 worker larvae of known age were transferred for queen rearing. A grafting frame of two bars carrying 20 queen cell cups was made from wax. Both 1-day-old and 2-day-old larvae were grafted reciprocally to each colony in order to equalize the nursing conditions. Ten days after transfer, queen cells were removed from the bar and they were placed in mating colonies with a plastic cage. Mating colonies were established with two combs covered with nurse bees two days before transfer, honey, and pollen sources were equalized. Emergence, mating, and oviposition of queens were followed in these colonies. Twenty similar-sized local honeybee colonies were left queenless in order to determine emergency queen rearing under natural and uncontrolled conditions. There were worker eggs and larvae of unknown ages in de-queened colonies. The queen rearing process and selection was left to worker bees. The minimum requirements were provided without supplemental feeding to the trial colonies to ensure beekeeper conditions.

Morphological and reproductive characters. Queen cell length and width were determined via digital caliper $(0.001 \mathrm{~mm})$. The newly emerged queens were weighed (mg) via (Radwag PS 750.R2; $0.001 \mathrm{~g}$ ), paint marked, and 
released back to their own colonies. One month after oviposition, the queens were anesthetized one by one at $-20^{\circ} \mathrm{C}$ (3-4 minutes) and they were dissected in order to determine the morphological and reproductive organ characteristics with a stereomicroscope (Leica S8 APO and LAS Software). The queens were dissected according to the method of (5) and (6). For the dissection process, queens were mounted with insect needles on a paraffin block. Wings and legs of queens were dissected and were mounted on microscope slides. The abdomen was opened and the roof was lifted off carefully, the alimentary canal was removed. The wet ovary weight $(\mathrm{mg})$ was determined during dissection then ovaries were placed in the physiological fluid to determine the number of ovarioles. The numbers of ovarioles were determined by the real-time counting method under microscope. The spermatheca was removed and diameter was measured without tracheal net. Following the dissection of reproductive organs, morphological characteristics; head width $(\mathrm{mm})$, thorax width $(\mathrm{mm})$, right forewing length $(\mathrm{mm})$, right forewing width $(\mathrm{mm})$, hindwing length $(\mathrm{mm})$ and hindwing width $(\mathrm{mm})$, hindleg length (femur + tibia + basitarsus length) (mm) were measured according to (25). Microscope images of the investigated morphological and reproductive organ characteristics are presented in Fig. 1.

Statistical analysis. Variance analysis (ANOVA) and Tukey's multiple comparison tests were applied to three different groups of queen honey bee morphological and reproductive organ characteristics. Correlations between characters were found by Pearson correlation method. All statistical analyses were performed using Portable MiniTab v16.1.

\section{Results and discussion}

With the larvae grafting method, 16 queens were raised from transferred 1-day-old larvae, 13 returned from the mating flight, and started to lay eggs. Fifteen queens were raised from transferred 2-day-old larvae 13 returned from the mating flight and started to lay eggs. In the case of emergency queen rearing, 12

Tab. 1. Grafting, emergence and mating success of queens

\begin{tabular}{|l|c|c|c|c|}
\hline \multicolumn{1}{|c|}{ Group } & $\mathrm{n}$ & Grafting success (\%) & Emergence rate (\%) & Mating succes (\%) \\
\hline Emergency queen cells & 20 & - & 75.0 & 80.0 \\
One-day old larvae & 20 & 90 & 88.8 & 81.2 \\
\hline Two-day old larvae & 20 & 85 & 88.2 & 86.6 \\
\hline
\end{tabular}

Tab. 2. Morphological characteristics of queens according to rearing method

\begin{tabular}{|l|l|l|l|}
\hline \multicolumn{1}{|c|}{ Group/Characters } & Emergency queen cells & \multicolumn{1}{|c|}{ 1 day old larvae } & \multicolumn{1}{c|}{2 day old larvae } \\
\hline Head width $(\mathrm{mm})$ & $3.53 \pm 0.176^{\mathrm{b}}$ & $3.74 \pm 0.067^{\mathrm{a}}$ & $3.53 \pm 0.168^{\mathrm{a}}$ \\
Thorax width $(\mathrm{mm})$ & $3.96 \pm 0.228$ & $4.12 \pm 0.312$ & $4.01 \pm 0.372$ \\
\hline Forewing length $(\mathrm{mm})$ & $8.99 \pm 0.346^{\mathrm{b}}$ & $9.34 \pm 0.108^{\mathrm{a}}$ & $9.31 \pm 0.169^{\mathrm{a}}$ \\
\hline Forewing width $(\mathrm{mm})$ & $3.08 \pm 0.151^{\mathrm{b}}$ & $3.23 \pm 0.092^{\mathrm{a}}$ & $3.14 \pm 0.087^{\mathrm{b}}$ \\
\hline Hind wing length $(\mathrm{mm})$ & $6.75 \pm 0.313$ & $6.92 \pm 0.159$ & $6.83 \pm 0.221$ \\
Hind wing width $(\mathrm{mm})$ & $2.14 \pm 0.080$ & $2.15 \pm 0.062$ & $2.14 \pm 0.051$ \\
\hline Hind leg length $(\mathrm{mm})$ & $9.01 \pm 0.268$ & $9.08 \pm 0.154$ & $9.03 \pm 0.306$ \\
\hline
\end{tabular}

Explanation: ${ }^{\mathrm{a}, \mathrm{b}}$ - Different letters represent statistically significant and different groups in the same row $(\mathrm{P}<0.05)$ queens returned back from the mating flight and started oviposition. Pre-oviposition time averages of queens in grafting groups were 11 days. All morphological and reproductive organ characteristics were measured on these queens. Grafting, emergence, and mating success of queens are given in Table 1.

The fresh weights of the queen bees were $151.67 \mathrm{mg}$, $178.38 \mathrm{mg}, 167.15 \mathrm{mg}$ rearing from emergency cells $(\mathrm{n}=12), 1$-day-old $(\mathrm{n}=13)$ and 2-day-old $(\mathrm{n}=13)$ larvae, respectively $(\mathrm{P}<0.05)$. The highest mean was found in queens reared from 1-day-old larvae and the lowest mean was found in queens reared from emergency queen cells according to the weight at the emergence.

In a study which examined the queen quality of Apis mellifera meda, (20) stated that the queens reared from 1-day-old larvae had higher weight $(158.83 \mathrm{mg}$ ) than those from two-days, three-days, and emergency queen cells. According to (16), queens raised from eggs 48-72 h old (173 mg), were significantly heavier than those raised from larvae $0-24 \mathrm{~h}$ old $(156 \mathrm{mg})$ or larvae $24-48 \mathrm{~h}$ old $(148 \mathrm{mg})$. The age of grafted larvae had a statistically significant effect on queen weight according to (21). They found queens' weight as $173.59 \mathrm{mg}$ reared from 1-day-old, and $166.9 \mathrm{mg}$ from 2-day-old larvae. In a two-year study, the mean weight of queens at emergence for Anatolian honeybee Aegean ecotype (Apis mellifera anatoliaca), was $178.8 \mathrm{mg}$ (36). According to (18), the weight of queens at emergence had an effect on the weights at 3 days after emergence, at the start of oviposition, at 3 days after the start of oviposition, and at 1 month after the start of oviposition. In a previous study of (23), local honey bees of Sanliurfa, queen weight at emergence were determined as $170 \mathrm{mg}$ for the light queen group, and $211 \mathrm{mg}$ for the heavy queen group.

Morphological characteristics of queens. In this study, seven morphological characteristics of queens were examined. Morphological characteristics of the queens reared from emergency cells, 1-day-old and 2-day-old larvae are presented in Table 2.

The differences were significant in terms of head width, forewing length, and forewing width characteristics. The examination of the other morphological characteristics showed that the queens reared from the 1-day-old larva have higher means than the other group queens, all but 2-day-old larvae and emergency queen cell groups were similar.

A study measuring the effects of the age of grafted larvae and additional feeding on 9 morphological characteristics of queens indicates that the age of the larvae importantly 
affects the morphological characteristics and the quality of the reared queens. The values from measurements of external characteristics of emergency queens were lower than those of queens reared from one-day-old larvae, but nevertheless higher than those of queens reared from three-day-old-larvae (20). Queens reared from 48-72 h old eggs had significantly longer thoraces than queens reared from 24-48 h old eggs or from 0-24 h old larvae (16). When morphological characteristics of queens were compared to present study, similarities were observed in terms of forewing characteristics. No differences were found in the thorax or head width between high-quality and low-quality queen groups (24). Morphological measures of queen size proved that high-quality queens were statistically heavier than low-quality queens. The age of grafted larvae had no significant effect on head width, head length, wing width while it significantly affected body length, thorax width and length, and wing length of the queen (21). The results of this study showed a significant difference in head width, thorax width, and forewing width characteristics between the grafting and emergency case groups $(\mathrm{P}<0.05)$. In this study, low averages were observed in terms of morphological characteristics of the queens of local honey bees.

Reproductive organ characteristics of queens. According to the rearing method, wet ovary weight, the number of ovarioles, and spermatheca diameter of the queens were given in Table 3. The differences between the group mean for each queen quality characteristics were found significant $(\mathrm{P}<0.05)$. The highest average wet ovary weight $(51 \mathrm{mg})$, number of ovarioles (296 pcs), and the spermatheca diameter $(1.21 \mathrm{~mm})$ were found in queens reared from 1-day-old larvae.

The weight of the ovaries in the queen depends not only on the number of ovarioles but also on the number and development of the eggs (28). According to (18), wet ovary weight was found $52.0 \mathrm{mg}$ in the light queen group, $54.8 \mathrm{mg}$ in the moderate queen group and $54.5 \mathrm{mg}$ in the heavy queen group. The wet ovary weight of the light queens (Apis mellifera caucasica), was similar to the results of queens raised from 1-dayold larvae in this study. The number of ovarioles found in the ovaries of the queen's range from 100-180 per ovary. The average number of ovarioles in 75 queen bees was found 320, ranging from 233 to 438 pcs. (17). In all grafted larvae and egg age groups, the numbers of ovarioles of the queens were found high (16) compared to this study.

Spermatheca size can be determined with/without the tracheal net, and for high-quality queens its diameter should be larger than $1.2 \mathrm{~mm}$ (5). In a two-year study, the spermatheca diameter of queens for

Explanation: ${ }^{\mathrm{a}, \mathrm{b}}$ - Different letters represent statistically significant and different groups in the same column $(\mathrm{P}<0.05)$

\begin{tabular}{|l|l|}
\hline $268 \pm 27.48^{\mathrm{b}}$ & $1.14 \pm 0.030^{\mathrm{b}}$ \\
\hline $296 \pm 19.04^{\mathrm{a}}$ & $1.21 \pm 0.043^{\mathrm{a}}$ \\
\hline $285 \pm 17.28^{\mathrm{ab}}$ & $1.16 \pm 0.048^{\mathrm{b}}$ \\
\hline
\end{tabular}

Tab. 4. Correlation matrix of morphological and reproductive organ characters $(r, P)$

\begin{tabular}{|c|c|c|c|c|c|c|c|c|c|c|}
\hline Characters & WE & HW & FWL & FWW & HWL & HWW & TW & HLL & WOW & NO \\
\hline Head Width & $\begin{array}{l}0.426 \\
0.019\end{array}$ & & & & & & & & & \\
\hline Forewing Length & $\begin{array}{l}0.373 \\
0.042\end{array}$ & $\begin{array}{l}0.369 \\
0.045\end{array}$ & & & & & & & & \\
\hline Forewing Width & $\begin{array}{l}0.216 \\
0.253\end{array}$ & $\begin{array}{l}0.220 \\
0.243\end{array}$ & $\begin{array}{l}0.691 \\
0.000\end{array}$ & & & & & & & \\
\hline Hindwing Length & $\begin{array}{l}0.225 \\
0.233\end{array}$ & $\begin{array}{l}0.200 \\
0.290\end{array}$ & $\begin{array}{l}0.569 \\
0.001\end{array}$ & $\begin{array}{l}0.466 \\
0.009\end{array}$ & & & & & & \\
\hline Hindwing Width & $\begin{array}{l}0.188 \\
0.319\end{array}$ & $\begin{array}{l}0.152 \\
0.423\end{array}$ & $\begin{array}{l}0.494 \\
0.006\end{array}$ & $\begin{array}{l}0.186 \\
0.324\end{array}$ & $\begin{array}{l}0.665 \\
0.000\end{array}$ & & & & & \\
\hline Thorax Width & $\begin{array}{l}0.173 \\
0.360\end{array}$ & $\begin{array}{l}0.464 \\
0.010\end{array}$ & $\begin{array}{l}0.124 \\
0.514\end{array}$ & $\begin{array}{l}0.193 \\
0.308\end{array}$ & $\begin{array}{l}0.138 \\
0.467\end{array}$ & $\begin{array}{r}-0.094 \\
0.623\end{array}$ & & & & \\
\hline Hindleg Length & $\begin{array}{l}0.067 \\
0.724\end{array}$ & $\begin{array}{l}0.102 \\
0.591\end{array}$ & $\begin{array}{l}0.157 \\
0.407\end{array}$ & $\begin{array}{l}0.324 \\
0.081\end{array}$ & $\begin{array}{l}0.347 \\
0.061\end{array}$ & $\begin{array}{l}0.021 \\
0.911\end{array}$ & $\begin{array}{r}-0.014 \\
0.943\end{array}$ & & & \\
\hline Wet Ovary Weight & $\begin{array}{l}0.356 \\
0.053\end{array}$ & $\begin{array}{l}0.366 \\
0.047\end{array}$ & $\begin{array}{r}-0.040 \\
0.832\end{array}$ & $\begin{array}{l}0.149 \\
0.433\end{array}$ & $\begin{array}{l}0.231 \\
0.219\end{array}$ & $\begin{array}{r}-0.087 \\
0.649\end{array}$ & $\begin{array}{l}0.209 \\
0.267\end{array}$ & $\begin{array}{l}0.096 \\
0.612\end{array}$ & & \\
\hline Number of Ovarioles & $\begin{array}{l}0.633 \\
0.000\end{array}$ & $\begin{array}{l}0.186 \\
0.324\end{array}$ & $\begin{array}{l}0.361 \\
0.050\end{array}$ & $\begin{array}{l}0.308 \\
0.097\end{array}$ & $\begin{array}{l}0.199 \\
0.293\end{array}$ & $\begin{array}{l}0.033 \\
0.864\end{array}$ & $\begin{array}{r}-0.011 \\
0.953\end{array}$ & $\begin{array}{l}0.135 \\
0.477\end{array}$ & $\begin{array}{l}0.357 \\
0.053\end{array}$ & \\
\hline Spermatheca Diameter & $\begin{array}{l}0.467 \\
0.009\end{array}$ & $\begin{array}{l}0.604 \\
0.000\end{array}$ & $\begin{array}{l}0.309 \\
0.097\end{array}$ & $\begin{array}{l}0.255 \\
0.175\end{array}$ & $\begin{array}{l}0.254 \\
0.175\end{array}$ & $\begin{array}{r}-0.025 \\
0.898\end{array}$ & $\begin{array}{l}0.319 \\
0.086\end{array}$ & $\begin{array}{l}0.304 \\
0.102\end{array}$ & $\begin{array}{l}0.445 \\
0.014\end{array}$ & $\begin{array}{l}0.324 \\
0.080\end{array}$ \\
\hline
\end{tabular}

Explanations: WE - weight at emergence; HW - head width; FWL - forewing length; FWW - forewing width; HWL - hindwing length; HWW - hindwing width; TW - thorax width; HLL - hindleg length; WOW - wet ovary weight; NO - Number of Ovarioles 
Anatolian honeybee Aegean ecotype was found to be $1.12 \mathrm{~mm}$ (36). When queens were categorized into three groups as heavy, medium, and light, the diameters of spermatheca were found to be 1.25, 1.06, and $0.86 \mathrm{~mm}$ respectively (1). According to the present study, the spermatheca diameter of queens reared from only one-day-old larvae were at the reported limit value and the other groups showed lower values. According to (13), spermatheca diameter was found to be 1.063 and $1.027 \mathrm{~mm}$, weight at emergence was 166.47 and $161.96 \mathrm{mg}$, hind leg length was $9.460 \mathrm{~mm}$ and $9.368 \mathrm{~mm}$ in queens reared from one- and twoday-old larvae, respectively. Compared to the results of the present study, there are similarities in some characteristics. The quality of queens was determined reared from newly hatched and 2-day-old larvae (32). They came up with averages in terms of weight of queens, thorax width, forewing length, and the numbers of ovarioles compared to the present study. Queen weights at emergence, diameters of spermatheca were found to be higher by the Doolittle method than the natural queen cell method (9). As in this study, the queens raised from one-day-old larvae showed higher values than the emergency queens.

Correlations. Correlation coefficients between all measured characters were calculated (Tab. 4). As expected, the highest correlation was found between the forewing width, and forewing length characters $(r=0.691 ; P<0.01)$. Significant positive correlations were discovered between the weight at emergence and head width $(\mathrm{r}=0.426 ; \mathrm{P}<0.05)$, and between weight at emergence and forewing length $(\mathrm{r}=0.373 ; \mathrm{P}<0.05)$. No correlation was found between wet ovary weight and weight at emergence. A significant positive correlation was found between the weight at emergence and the number of ovarioles $(\mathrm{r}=0.633 ; \mathrm{P}<0.01)$, and also between the weight at emergence and spermatheca diameter $(\mathrm{r}=0.467 ; \mathrm{P}<0.05)$. The wet ovary weight was significantly correlated with the diameter of spermatheca $(r=0.445 ; \mathrm{P}<0.05)$. Insignificant and negative correlations between characters were also found (Tab. 4).

The positive correlation between queen weight at emergence and number of ovarioles was similar to the findings of (42), however, some researchers $(16,17)$ have stated that there is no correlation between these characteristics. In addition, in a study (18) correlation was not determined between the weight at emergence and the wet weight of ovaries, similar to the present study. They explained this as follows: the weight of ovaries in queens does not only depend on the number of ovarioles but also the development stage of eggs and the number of them. Queen weight correlated with ovary weight and ovary weight low correlated with the number of ovarioles (15). Carniolan queens (Apis mellifera carnica) were found to have higher average weight at emergence and higher wet ovary weight than the finding of this study.
There was no correlation between thorax width and reproductive organs, while head width was correlated with ovary weight and spermatheca diameter. In one study, a direct positive effect of queen thoracic width on mating success and number of stored sperms has been reported by (8). Statistically important correlations were found between queen weight and the egg-laying rate of the queens $(r=0.90)$, the number of spermatozoa in the spermatheca $(r=0.97)$, and diameter of the spermatheca $(r=0.98)(1)$. According to the findings of this study a significant correlation, albeit low, was observed between queen weight and spermatheca diameter. Queen cell length mean $(24.72 \mathrm{~mm})$ for 1-day old larvae group was found similar to findings $(9,13,36)$.

In situations of queen replacement, workers are in general expected to take advantage by optimizing the reproductive characteristics of queens, but possible disputes among workers could end in suboptimal queens (34). Since the aim was to get an idea about the quality of queens raised in an emergency situation under the beekeeper's conditions, the lack of regular monitoring of the queens is seen as a deficiency of this study. However, previous studies $(16,20,26,35)$ showed that it is necessary to examine in more detail the queen rearing process in an emergency. For commercial honey-producing beehives, queen replacement must be done annually. Some commercial beekeepers raise some of their queens from their own colonies. They also perform this queen rearing process by preparing a new queenless colony as in an emergency queen rearing situation. The workers decide which queen to rise in these colonies. Many commercial beekeepers buy the pure or hybrid queens they need from commercial queen producers. The quality and performance of queens produced by commercial queen producers in each region are not known in detail. In our country and in the world, the effects of many honey bee diseases and pests as well as the effects of poor quality queens have been reported on the increasing colony losses in recent years. There are typical complaints attributed to poor quality queens with early queen supersedure and depletion of sperm stores. Therefore, it has become important for beekeepers and queen breeders to raise local, quality and disease-pest free queens specific to certain regions while preserving genetic diversity $(10$, $29,39,40)$.

There are many factors affecting the queens' quality. A queen should be healthy as well as of good reproductive potential and should be perfect in terms of hormones and pheromones. At the same time, the quality of the drones she mated and the workers produced by her directly affect the colony performance. However, it should be noted that each queen performs best in its ecology. According to the grafting method, it is recommended to use 0-24-hour larvae in queen rearing. However, our selection of larvae of the appropriate age from the good source colony does not mean that we will breed the best queens in terms of morphological, physi- 
ological, and reproductive characteristics. Even if all conditions are met to raise the queen's quality, workers in starter and mating colonies determine which queens can live. In this study, a part of the quality markers of the local queens was discussed. Further detailed studies will be needed. According to the results of the study, rearing methods affect some of the morphological and reproductive characteristics of local queens and have lower values than some other honey bee genotypes in terms of these characteristics. This genotype, which adapted to the insufficient flora, hot and arid climatic conditions, can be improved in terms of some features. Genetic diversity is an important requirement in bee breeding. Breeding of local honey bee genotypes is also of great importance for sustainable beekeeping.

\section{References}

1. Akyol E., Yeninar H., Kaftanoğlu O.: Live weight of queen honey bees (Apis mellifera L.) predicts reproductive characteristics. J. Kansas Entomol. Soc. 2008, 81, 92-100.

2. Amiri E., Strand M. K., Rueppell O., Tarpy D. R.: Queen quality and the impact of honey bee diseaseson queen health: potential for interactions betweentwo major threats to colony health. Insects $2017,8,48$.

3. Amiri E., Strand M. K., Tarpy D. R., Rueppell O.: Honey bee queens and virus infections. Viruses 2020, 12, 2-12, doi:10.3390/v12030322.

4. Butler C. G.: The process of queen supersedure in colonies of honeybees (Apis mellifera L.). Insect. Soc. 1957, 4, 211-223.

5. Carreck N. L., Andree M., Brent C. S., Cox-Foster D., Dade H. A., Ellis J. D., Hatjina F, van Englesdorp D.: Standard methods for Apis mellifera anatomy and dissection. J. Apic. Res. 2013, 52, 1-40

6. Dade H. A.: Anatomy and Dissection of the Honeybee. International Bee Research Association and Northern Bee Books, 1962, pp. 196.

7. Dedej S., Hartfelder K., Aumeier P., Rosenkranz P., Engels W.: Caste determination is a sequential process: effect of larval age at grafting on ovariole number, hind leg size and cephalic volatiles in the honey bee (Apis mellifera carnica). J. Apic. Res. 1998, 37, 183-190.

8. Delaney D. A., Keller J. J., Caren J. R., Tarpy D. R.: The physical, insemination, and reproductive qualityof honey bee queens (Apis mellifera L.). Apidologie 2011, 42, 1-13

9. Dodologlu A., Emsen B., Genc F.: Comparison of some characteristics of queen honey bees (Apis mellifera L.) reared by using Doolittle method and natural queen cells. J. Appl. Anim. Res. 2004, 26, 113-115.

10. Engelsdorp D. van, Meixner M. D.: A historical review of managed honey bee populations in Europe and the United States and the factors that may affect them. J. Invertebr. Pathol. 2010, 103, S80-S95.

11. Fell R. D., Morse R. A.: Emergency queen cell production in the honey bee colony, Insect. Soc. 1984, 31, 221-237.

12. Gąba J., Zajdel B., Skorupka M., Ostaszewska T., Kamaszewski M.: Effect of honey flow on acceptance of bee eggs at different age in rearing colonies. Med. Weter. 2014, 70, 760-761.

13. Gençer H. V., Firatl Ç.: Comparison of structural characters of honey bee queens (Apis mellifera anatoliaca) reared from one and two day old larvae. J. Agric. Sci. 1999, 5, 13-16.

14. Gilley D. C., Tarpy D. R., Land B. B.: Effect of queen quality on interactions between workers and dueling queens in honeybee (Apis mellifera L.) colonies. Behav. Ecol. and Sociobi. 2003, 55, 190-196.

15. Gregorc A., Smodǐ̌ Škerl M. I.: Characteristics of honey bee (Apis mellifera carnica Pollman, 1879) queens reared in Slovenian commercial breeding stations. J. Apic. Sci. 2015, 59, 5-12.

16. Hatch S., Tarpy D. R., Fletcher D. J. C.: Worker regulation of emergency queen rearing in honey bee colonies and the resultant variation in queen quality. Insect. Soc. 1999, 46, 372-377.

17. Jackson J. T., Tarpy D. R., Fahrbach S. E.: Histological estimates of ovariole number in honey bee queens, Apis mellifera, reveal lack of correlation with other queen quality measures. J. Insect Sci. 2011, 11, 93.

18. Kahya Y., Gencer H. V., Woyke J.: Weight at emergence of honey bee (Apis mellifera caucasica) queens and its effect on live weights at the pre and post mating periods. J. Apic. Res. 2008, 47, 118-125.

19. Laidlaw H. H. Jr., Page R. E. Jr.: Queen Rearing and Bee Breeding. Wicwas, Cheshire 1997, pp. 224.
20. Mahbobi A., Farshineh-Adl M., Woyke J., Abbasi S.: Effects of the age of grafted larvae and the effects of supplemental feeding on some morphological characteristics of Iranian queen honey bees (Apis mellifera meda, Skorikov 1929). J. Apic. Res. 2012, 56, 93-98.

21. Okuyan S., Akyol E.: The effects of age and number of grafted larvae on some physical characteristics of queen bees and acceptance rate of queen bee cell. Turkish J. Agric-Food Sci. and Tech. 2018, 6, 1556-1561.

22. Ozmen Ozbakır G., Firatl C.: Morphometric classification of honeybee populations (Apis mellifera L.) along the southeast border of Turkey. Bulg. J. Agric. Sci. 2013, 19, 1396-1400.

23. Oztokmak A., Ozmen Ozbakır G.: Effects of queen emergence weight on some behavioral characteristics and colony performance parameters in Sanliurfa local honeybees (Apis mellifera L.). Harran J. Agric. And Food Sci. 2017, 21, 385-393, doi: 10.29050/harranziraat.323352.

24. Rangel J., Keller J. J., Tarpy D. R.: The effects of honey bee (Apis mellifera L.) queen reproductive potential on colony growth. Insect. Soc. 2013, 60, 65-73, doi: 10.1007/s00040-012-0267-1.

25. Ruttner F: Biogeography and Taxonomy of Honeybees. Springer Verlag, Berlin 1988, pp. 284.

26. Sagili R. R., Metz B. N., Lucas H. M. Chakrabarti P., Breece C. R.: Honey bees consider larval nutritional status rather than genetic relatedness when selecting larvae for emergency queen rearing. Sci. Rep. 2018, 8, 7679.

27. Schneider S. S., DeGrandi-Hoffman G.: The influence of worker behavior and paternity on the development and emergence of honey bee queens, Insect. Soc. 2002, 49, 306-314.

28. Shehata S. M., Townsend G. F., Shuel R. W.: Seasonal physiological changes in queen and worker honeybees. J. Apic. Res. 1981, 20, 69-78.

29. Smith K. M., Loh E. H., Rostal M. K., Zambrana-Torrelio C. M., Mendiola L., Daszak P.: Pathogens, pests, and economics: Drivers of honey bee colony declines and losses. EcoHealth 2013, 10, 434-445.

30. Souza D. A. De, Huang M. H., Tarpy D. R.: Experimental improvement of honey bee (Apis mellifera L.) queen quality through nutritional and hormonal supplementation. Apidologie 2019, 50, 14-27.

31. Tarpy D. R., Gilley D. C., Seeley T. D.: Levels of selection in a social insect: a review of conflict and cooperation during honey bee (Apis mellifera) queen replacement. Behav. Ecol. and Sociobiol. 2004, 55, 513-523.

32. Tarpy D. R., Hatch S., Fletcher D. J. C.: The influence of queen age and quality during queen replacement in honey bee colonies. Anim. Behav. 2000, 59, 97-101.

33. Tarpy D. R., Keller J. J., Caren J. R., Delaney D. A.: Experimentally induced variation in the physical reproductive potential and mating success in honey bee queens. Insect. Soc. 2011, 58, 569-574.

34. Tarpy D. R., Simone-Fenstrom M., Linksvayer T. A.: Honey bee colonies regulate queen reproductive traits by controlling which queens survive to adulthood. Insect. Soc. 2016, 63, 169-174.

35. Tofilski A., Czekonska K.: Emergency queen rearing in honeybee colonies with brood of known age. Apidologie 2004, 35, 275-282.

36. Uçak Koç A., Karacaoğlu M.: Reproductive traits of Aegean ecotype of Anatolian queen honey bee. J. Adnan Menderes Uni. Agric. Fac. 2005, 2, 73-77.

37. Villar G., Hefetz A., Grozinger C. M.: Evaluating the effect of honey bee (Apis mellifera) queen reproductive state on pheromone-mediated interactions with male drone bees. J. Chem. Ecol. 2019, 45, 588-597, doi: 10.1007/ s10886-019-01086-0.

38. Visscher P. K.: Effect of location within the nest on acceptance of queen cells in honeybee colonies. J. Apic. Res. 1986, 25, 154-157.

39. Walsh E. M., Rangel J.: Local honey beequeen production and quality, Bee World 2016, 93, 2, 30-32, doi: 10.1080/0005772X.2016.1211501.

40. Walsh E. M., Sweet S., Knap A., Ing N., Rangel J.: Queen honey bee (Apis mellifera) pheromone and reproductive behavior are affected by pesticide exposure during development. Behavioral Ecology and Sociobiology 2020, 74, 33, doi: 10.1007/s00265-020-2810-9.

41. Winston M. L.: The Biology of the Honeybee. Harvard University Press, Cambridge 1987, pp. 281.

42. Woyke J.: Correlation between the age at which honeybee brood was grafted, characteristics of the resultant queens and result of insemination. J. Apic. Res. 1971, 10, 45-55.

43. Woyke J.: Rearing conditions and number of sperms reaching the queens spermatheca. Proceedings of $21^{\text {st }}$ ApimondiaCongress, (14-17 August 1967 , University of Maryland, USA), Apimondia Publishing House, Bucharest, Romania 1967, p. 232-234

Corresponding author: Assist. Prof. Dr. Gonca OZMENOZBAKIR, Harran University, Faculty of Agriculture, Department of Animal Science, Osmanbey Campus, 63300, Sanliurfa, Turkey; e-mail: gozmenozbakr@ harran.edu.tr 